
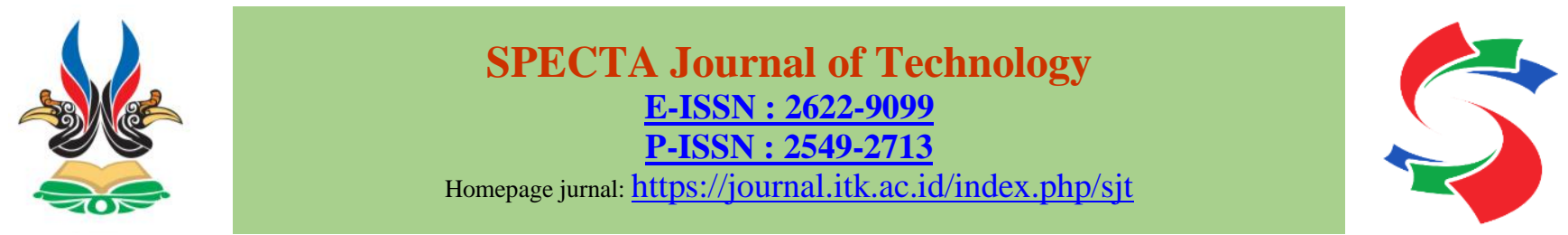

\title{
Pembuatan Aplikasi Sinkronisasi Data Akademik Dengan Feeder PDDIKTI Berbasis Web Service
}

\author{
M. Gilvy Langgawan Putra ${ }^{1}$, Sadriansyah ${ }^{2}$, Ahmad Maulana Fikri ${ }^{3}$, Hendy Maulana Jaya \\ Saputra $^{4}$, Brianto Rovi Harjanto ${ }^{5}$, Dimas Saputra ${ }^{6}$ \\ 1,2,3,4,5,6 Program Studi Sistem Informasi, Jurusan Matematika dan Teknologi Informasi, Institut Teknologi \\ Kalimantan, Balikpapan. Email: gilvy.langgawan@lecturer.itk.ac.id
}

\begin{abstract}
Every university or higher education institution in Indonesia, including the Kalimantan Institute of Technology, is required to update information about students studying. To update this information, the Ministry of Research, Technology, and Higher Education released the PDDIKTI Feeder application to simplify the administration of updating student data. The Kalimantan Institute of Technology as a university in Indonesia does not yet have a database system that is integrated with the Higher Education Database. Therefore, in its development, it is carried out by identifying problems, literary studies, needs analysis which consists of making use case diagrams, description of use cases, software requirements, hardware requirements, then the design and architecture stages consist of data mapping, data processing, structure navigation, and web service methods. Then coding and testing with a black box, resulting in 2 features tested successfully. PDDIKTI Feeder design and installation is required. The result of developing this application is a website-based information system with two features, namely the login feature and the synchronization feature. The login feature allows users to log in, and the synchronization feature allows updating data or adding data to the Higher Education Database. The test results of the login feature and the sync feature are successful.
\end{abstract}

Keywords: Data, PDDIKTI Feeder, Synchronization

\begin{abstract}
Abstrak
Setiap universitas ataupun Lembaga Pendidikan tinggi di Indonesia, termasuk Institut Teknologi Kalimantan wajib untuk memeperbarui informasi mengenai mahasiswa yang berkuliah. Untuk melakukan pembaruan informasi tersebut, Kementerian Riset, Teknologi, dan Pendidikan tinggi merilis aplikasi Feeder PDDIKTI untuk mempermudah administrasi pembaruan data mahasiswa. Institut Teknologi Kalimantan sebagai perguruan tinggi di Indonesia belum memiliki sistem basis data yang terintegrasi dengan Pangkalan Data Pendidikan Tinggi. Oleh karena itu, Dalam pengembangannya dilakukan dengan identifikasi masalah, studi literaur, analisis kebutuhan yang terdiri dari pembuatan use case diagram, Deskripsi use case, kebutuhan perangkat lunak, kebutuhan perangkat keras, kemudian tahapan desain dan arsitektur terdiri dari pemetaan data, proses data, struktur navigasi dan method web service. Selanjutnya dilakukan coding dan pengujian dengan black box, menghasilkan 2 fitur diujikan sukses.dibutuhkan perancangan dan installasi Feeder PDDIKTI. Hasil dari pengembangan aplikasi ini adalah berupa sistem informasi berbasi website dengan dua fitur, yakni fitur login dan fitur sinkronisasi. Fitur login memungkinkan pengguna untuk melakukan login, dan fitur sinkronisasi memungkinkan untuk memperbarui data atau menambahakan data pada Pangkalan Data Pendidikan Tinggi. Hasil pengujian terhadap fitur login dan fitur sinkronisasi adalah berhasil.
\end{abstract}

Kata Kunci: Data, Feeder PDDIKTI, Sinkronisasi 


\section{Pendahuluan}

Pangkalan Data Pendidikan Tinggi (PDDIKTI) merupakan kumpulan data dan informasi yang terintegrasi dengan data Pendidikan tinggi. Sumber data dan informasi PDDIKTI dari integrasi data dan informasi tersier yang dikelola oleh Direktorat Jenderal Pendidikan Tinggi. Manfaat data dan informasi dalam PDDIKTI meliputi: mendukung Universitas untuk mengizinkan pelaksanaan Program Studi, sebagai tempat terpusat penyimpanan pelaporan data baik akademik dan non-akademik, mendukung Sistem Penjaminan Mutu Internal (SPMI) dan Sistem Penjaminan Mutu Eksternal (SPME), peningkatan kebutuhan tolok ukur pendidikan, mendukung sistem skala perusahaan, menjamin keamanan data pada jaringan dan basis data, dan mendukung integritas dan konsistensi data (Kenali dan Fatoni, 2014). Dalam mendukung kegiatan pengumpulan data dan informasi dari Pendidikan Tinggi, maka dibuat sebuah aplikasi yang dinamakan Aplikasi Feeder PDDIKTI.

Aplikasi Feeder PDDIKTI adalah salah satu produk untuk menjamin kualitas, relevansi, keterjangkauan dan pemetaan data dan informasi. Feeder PDDIKTI dapat diakses untuk melanjutkan pendidikan tinggi sesuai dengan apa yang diamanatkan berdasarkan Keputusan Menteri Pendidikan Nasional 184 / U / 2001 pasal 5. Menurut UU No. 12 Tahun 2012 tentang Pendidikan Tinggi, Pasal 56 bahwa setiap Perguruan Tinggi harus melaporkan data dan juga informasi pada PDDKTI (Pemerintah Indonesia, 2012). Penggunaan Aplikasi Feeder PDDIKTI digunakan bersama dengan periode pelaporan data akademik yang harus dilaporkan oleh Perguruan Tinggi. Pelaporan ini dilakukan disemester ganjil maupun semester genap. Pada setiap semester, dibagi menjadi 2 (dua) tahapan pemeriksaan. Tahap pemeriksaan pertama yaitu rencana studi yang dilakukan dua bulan setelah masa perkuliahan dimulai dan tahap pemeriksaan kedua yaitu hasil studi dilakukan dua bulan setelah masa perkuliahan berakhir. Menurut Retnoningsih dan Utami (2013) Feeder PDDIKTI digunakan secara bersamaan dengan masa pelaporan data akademik yang harus dilaporkan oleh Perguruan Tinggi pada masing-masing bagian akademik (Widodo dkk., 2018). Data yang dilaporkan dapat berupa data kursus, data kurikulum, data mahasiswa (data mahasiswa reguler atau pertukaran mahasiswa), data nilai mahasiswa, transfer data mahasiswa jika ada, data kegiatan kuliah mahasiswa termasuk IPK dan kredit yang dilakukan, data status mahasiswa (cuti, non -aktif, berhenti berkuliah, lulus) dan data pengajaran dosen.

Institut Teknologi Kalimantan (ITK) adalah lembaga pendidikan tinggi yang dimiliki oleh Pemerintah Republik Indonesia. Institut Teknologi Kalimantan pertama kali didirikan pada tahun 2014. Dilaporkan dari situs resmi Institut Teknologi Kalimantan, pada tahun 2018, jumlah mahasiswa yang terdaftar adalah 3.000 mahasiswa, 164 dosen / dosen, dan 50 staf pendidikan. Sebagai lembaga Pendidikan tinggi miliki negara, Institut Teknologi Kalimantan wajib melakukan pelaporan data akademik melalui aplikasi Feeder PDDIKTI dengan ketentuan periode pelaporan yang sama setiap perguruan tinggi. Namun, proses pelaporan di Institut Teknologi Kalimantan masih dilakukan secara manual. Proses yang berlangsung saat ini yaitu dengan melaporkan satu per satu data akademik dalam basis data yang dimiliki ITK ke dalam aplikasi Feeder PDDIKTI. Hal ini menyebabkan proses pelaporan membutuhkan waktu yang lama dan membutuhkan lebih banyak sumber daya manusia untuk melakukan pelaporan. Oleh karena itu, untuk menyederhanakan dan mempercepat proses pelaporan, diperlukan sistem informasi yang dapat mensinkronisasikan data akademik ITK dengan Aplikasi Feeder PDDIKTI.

Beberapa penelitian telah dilakukan oleh peneliti lain yang berhubungan dengan Feeder PDDIKTI. Terdapat penelitian (Widarti, dkk., 2018) yang mengintegrasikan sistem informasi akademik terpadu (SIAKAT) dengan Feeder PDDIKTI. Setelah itu, juga terdapat penelitian Sutrisno dan Muhsi (2016) yang dilakukan untuk mensinkronisasikan antara sistem informasi akademik dengan Feeder PDDIKTI menggunakan kerangka kerja Laravel. Penelitian selanjutnya dari (Perwira dan Santosa, 2017) yang mengimplementasikan web service dalam pengintegrasian data akademik dengan replika pangkalan data DIKTI. Selain itu, terdapat juga penelitian oleh (Usman, 2020) yang membuat sistem informasi akademik dengan Feeder PDDIKTI berbasis android. Penelitian terakhir yang menjadi acuan dalam 
penelitian kali ini yaitu mengintegrasikan data akademik dengan aplikasi Feeder PDDIKTI berbasis web service (Widodo dkk., 2018).

Aplikasi sinkronisasi yang dibuat berbasis website, dimana website merupakan kumpulan dari beberapa halaman web yang saling terhubung (Abbas, 2013). Didalam website terdapat halaman yang biasanya disebut dengan home page. Home page merupakan halaman pertama yang dapat dilihat pada saat mengunjungi halaman website (Hendrianto, 2013). Dalam proses sinkronisasi, akan dibantu dengan web service. Web service menurut Manes (2001) yaitu sebagian informasi dan juga proses yang bisa diakses oleh siapa saja dan dimana saja, serta bisa menggunakan perangkat apa saja. Web service tidak terikat oleh sistem operasi maupun bahasa pemograman apapun (Priyambodo, 2005). Pengkodean program akan dilakukan dengan menggunakan bahasa markup HTML (Sasongko, 2017) dan bahasa pemrogram PHP (Lestanti dan Susana, 2016). Setelah itu, sebagai bentuk validasi program yang telah dibuat, akan dilakukan pengujian program tingkat pengguna dengan blackbox tesing yang menguji dari segi fungsional (Nurajizah, 2016).

\section{Metode}

Metode pengembangan sistem yang digunakan dalam penelitian ini, yaitu metode waterfall, dimana tahapan metode ini akan dilakukan secara berurutan dan memulai langkah selanjutnya hanya jika langkah sebelumnya telah selesai dilakukan dan disepakati. Adapun, metodologi dalam penelitian ini antara lain identifikasi masalah, studi literatur, analisis kebutuhan sistem, desain arsitektur dan aplikasi, pengkodean program dan pengujian program menggunakan blackbox testing tingkat pengguna. Diagram alir penelitian ini ditunjukkan oleh Gambar 1. Penerapan web service akan didesain terlebih dahulu pada tahapan desain arsitektur dan aplikasi. Hal ini bertujuan agar pengkodean program dapat berjalan sesuai dengan rencana kebutuhan sistem.

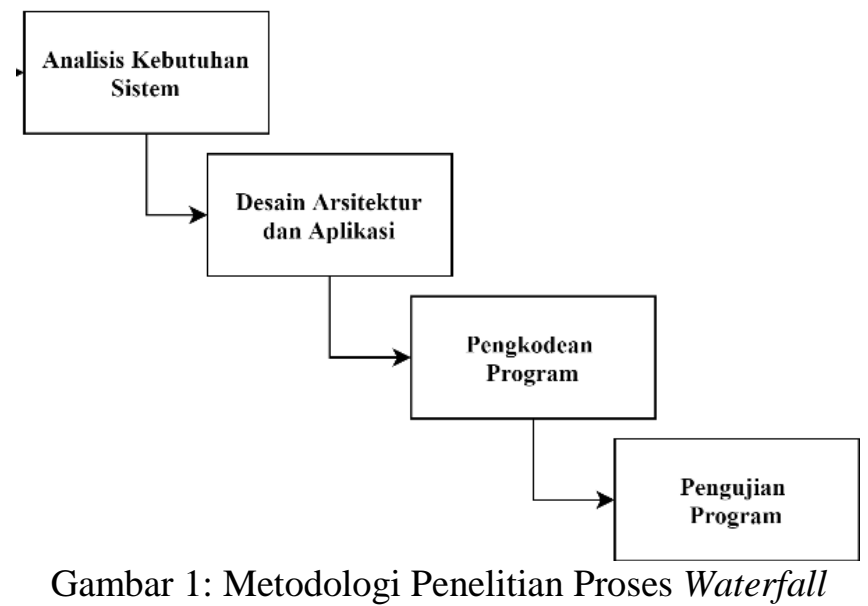

\section{Hasil dan Pembahasan}

\subsection{Analisa Kebutuhan}

\subsubsection{Analisis kebutuhan sistem}

Kebutuhan terkait sistem akan dimodelkan dalam use case diagram. Adapun use case diagram yang menjelaskan terkait kebutuhan pengguna terhadap sistem sebagai berikut. 


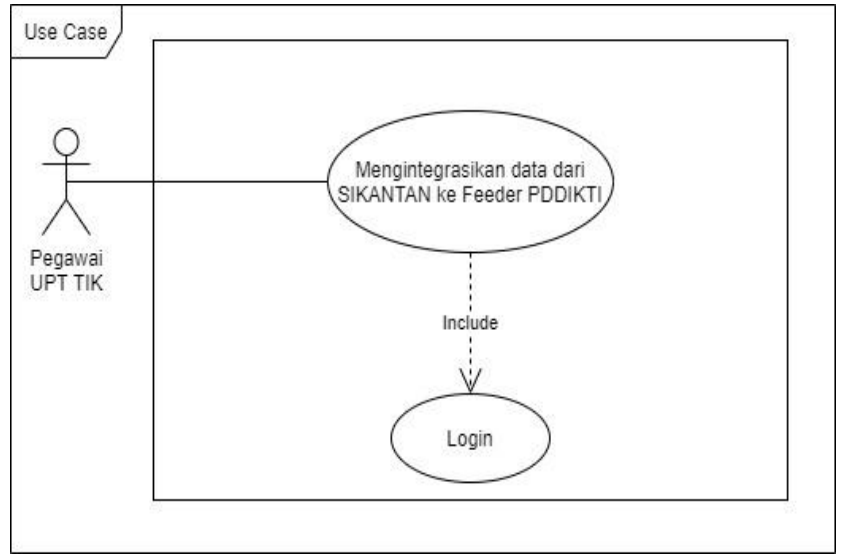

Gambar 2: Use Case Diagram

Tabel 1: Deskripsi Use Case Diagram

\begin{tabular}{llll}
\hline No & \multicolumn{1}{c}{ Nama Use Case } & \multicolumn{1}{c}{ Deskripsi } & Aktor \\
\hline 1 & Mengintegrasikan data dari & Sistem akan mengintegrasikan data dari & Admin \\
& $\begin{array}{l}\text { SIKANTAN ke Feeder } \\
\text { PDDIKTI }\end{array}$ & SIKANTAN ke Feeder PDDIKTI & \\
2 & Login & Sebelum mengakses fitur-fitur dengan & Admin \\
& & $\begin{array}{l}\text { hak akses administrator yang ada, } \\
\text { admin diharuskan untuk login dengan } \\
\text { data nama pengguna dan kata sandi. }\end{array}$ & \\
& & & \\
\hline
\end{tabular}

\subsubsection{Kebutuhan perangkat lunak}

Perangkat lunak merupakan aplikasi yang digunakan dalam membangun sistem integrasi data, antara lain.

1. XАMPP

2. Sandbox PDDIKTI

3. Visual Studio Code

4. Postman

5. Windows OS

\subsubsection{Kebutuhan perangkat keras}

Perangkat keras merupakan komponen-komponen fisik pembangun sistem komputer dan merupakan infrastruktur dari perangkat lunak yang digunakan. Berikut merupakan perangkat keras yang digunakan, antara lain.

1. Processor

2. RAM

3. Harddisk

4. Laptop atau PC.

\subsection{Desain Arsitektur dan Aplikasi}

Analisis terhadap proses dan pemetaan data perlu dilakukan sebelum data dari SIKANTAN ITK diinputkan dan dimigrasikan ke dalam aplikasi Feeder PDDIKTI. Berikut merupakan hasil dari analisis terhadap pemetaan dan proses data yang akan dimigrasikan.

Tabel 2: Pemetaan data

\begin{tabular}{llll}
\hline No & Jenis Data & \multicolumn{1}{c}{ Tabel Feeder } & Tabel Aplikasi ITK \\
\hline 1 & Data Mahasiswa & Mahasiswa & MSMHS \\
& & Mahasiswa_pt & \\
\hline
\end{tabular}




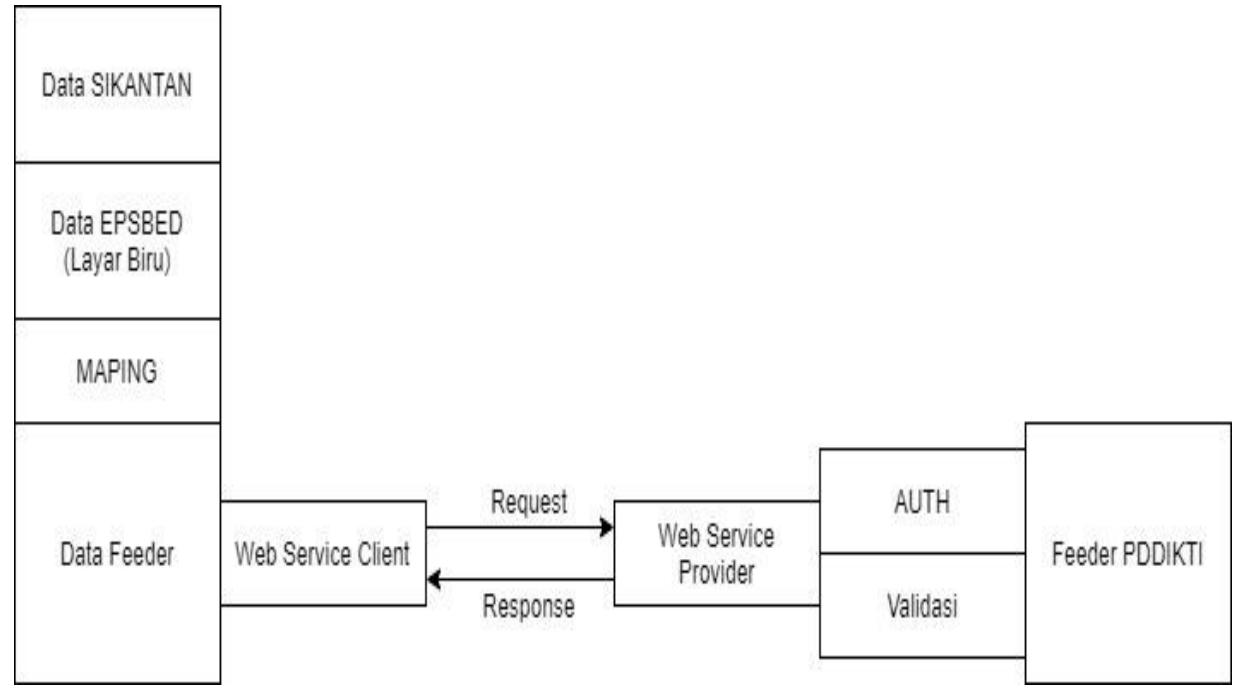

Gambar 3: Proses Data Sumber: Widodo dkk., 2018

Pada Gambar 2, digambarkan proses data yang akan dimigrasikan ke Feeder PDDIKTI. Data dasar yang berasal dari SIKANTAN ITK akan diolah dan divalidasi menggunakan aplikasi layar biru. Setelah itu, akan dilakukan proses pemetaan dan penyesuaian struktur data terhadap data yang ada pada feeder. Selanjutnya, web service dibutuhkan untuk request dan response untuk mengirim data ke aplikasi feeder. Token akan diperoleh dari proses auth dan validasi. Setelah data dinyatakan valid, maka akan masuk kedalam aplikasi Feeder PDDIKTI (Widodo dkk., 2018).

Berdasarkan kebutuhan yang telah dijelaskan, berikut merupakan desain navigasi dari aplikasi yang dibuat.

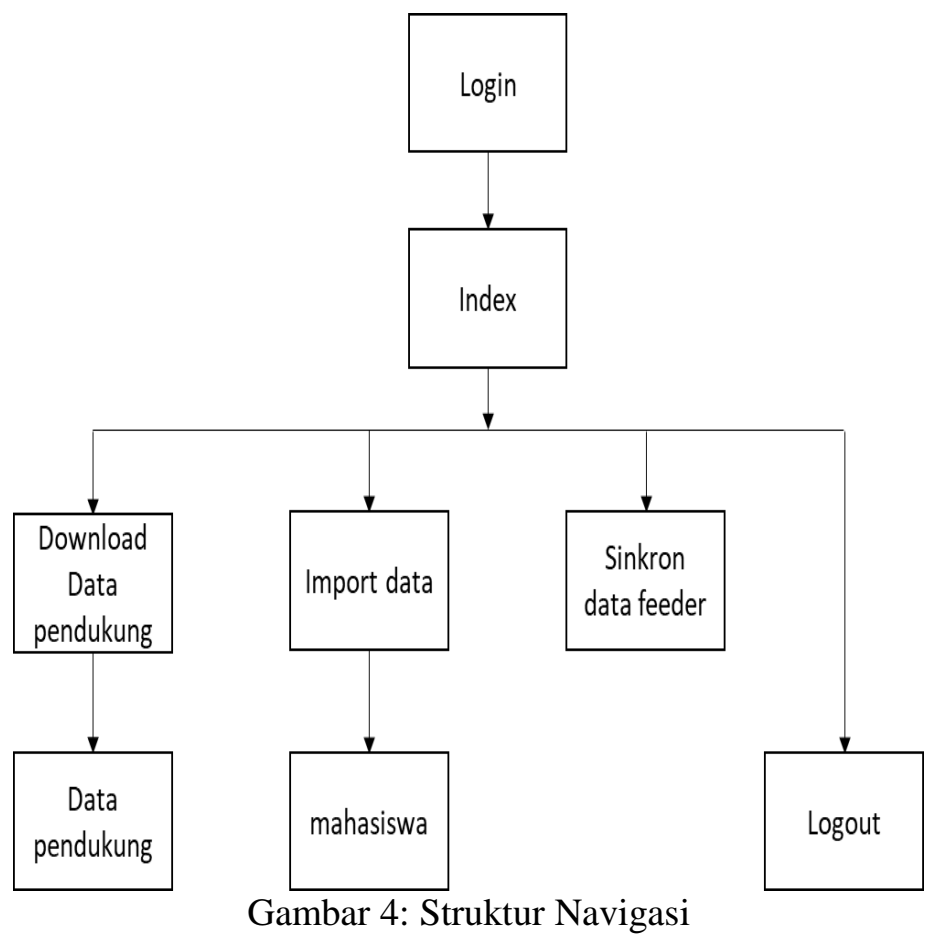

Sebelum melakukan pembuatan sistem, akan ditentukan method yang digunakan dalam aplikasi. Method akan diterapkan untuk mengolah data akademik yang akan dimasukkan kedalam aplikasi Feeder PDDIKTI. Berikut merupakan daftar metode-metode yang digunakan dalam aplikasi. 
Tabel 3: Daftar Method Web Service

\begin{tabular}{ccl}
\hline No & \multicolumn{1}{c}{ Method Web Service } & \multicolumn{1}{c}{ Keterangan } \\
\hline 1. & Get Token & $\begin{array}{l}\text { Method yang digunakan untuk mendapatkan token yang } \\
\text { dipakai sebagai parameter di fungsi web service lainnya. }\end{array}$ \\
2. Insert Biodata Mahasiswa & $\begin{array}{l}\text { Method yang digunakan untuk menambah biodata } \\
\text { mahasiswa dengan parameter yang dikirimkan berupa } \\
\text { token } \text { dan } \text { record inputan. } \\
\text { Method yang digunakan untuk memperbarui data biodata } \\
\text { mahasiswa }\end{array}$ \\
3. POST &
\end{tabular}

Alur dalam pemanfaatan web service untuk melakukan komunikasi data dengan aplikasi Feeder PDDIKTI digambarkan dalam gambar dibawah ini.

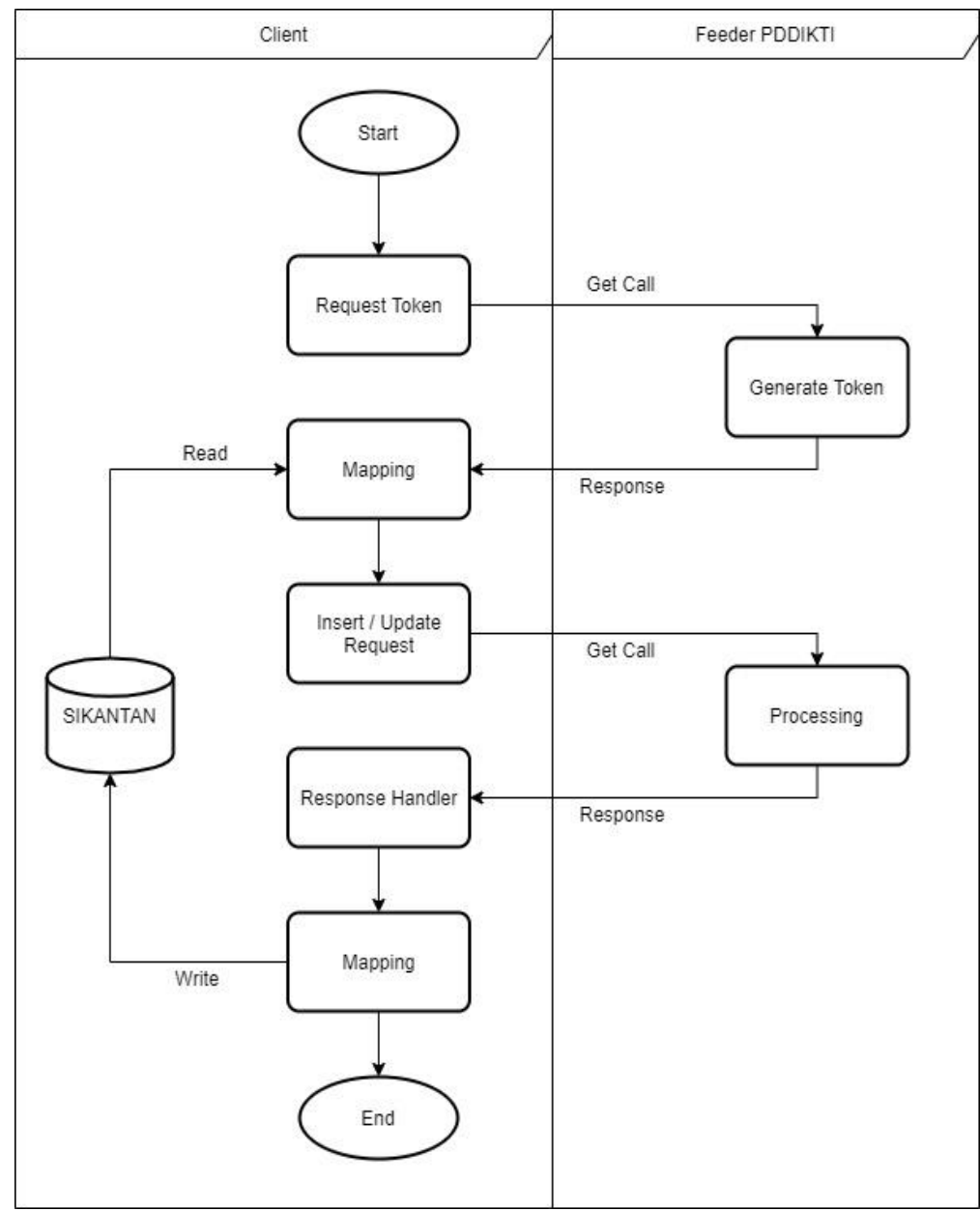

Gambar 5: Skema Method Web Service Sumber: Widodo dkk., 2018

\subsection{Pengkodean Program}

Dalam tahap ini, akan dilakukan pengkodean sistem untuk dapat diimplementasikan oleh pengguna. Berikut merupakan aplikasi yang telah diimplementasikan berbasis web service untuk sinkronisasi data akademik SIKANTAN di Institut Teknologi Kalimantan ke Feeder PDDIKTI. 


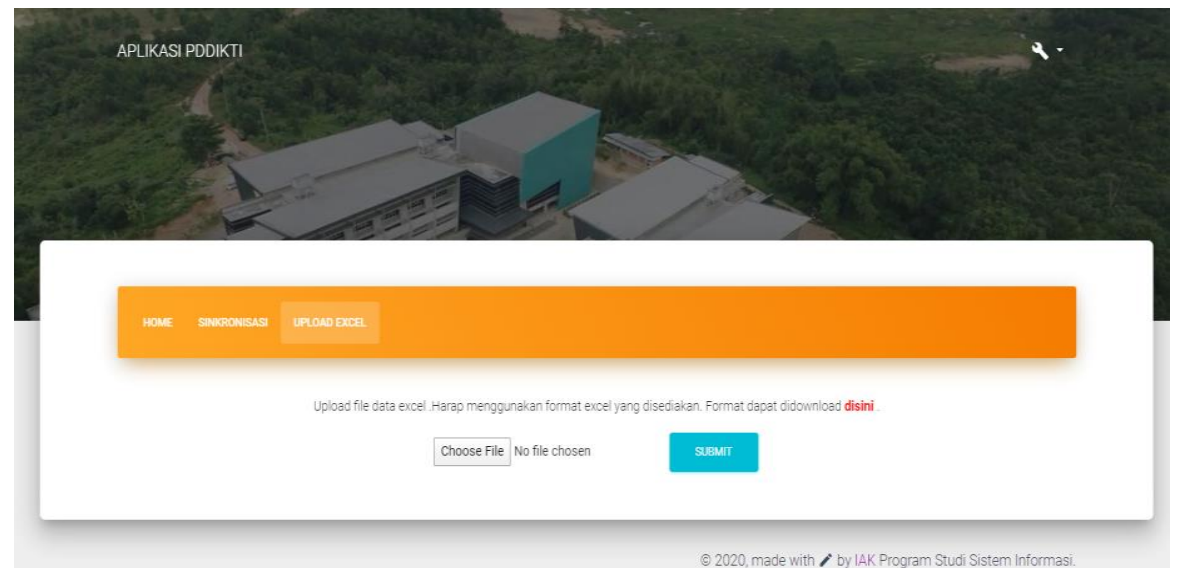

Gambar 6: Halaman Unggah Biodata Mahasiswa

Gambar 6 merupakan tampilan aplikasi untuk mengunggah file data biodata mahasiswa yang nanti akan disinkronkan, dalam tampilan tersebut ada link "di sini” yang digunakan untuk mengunduh excel yang menjadi template untuk penginputan data dan ada tombol untuk mengupload berkas excel.

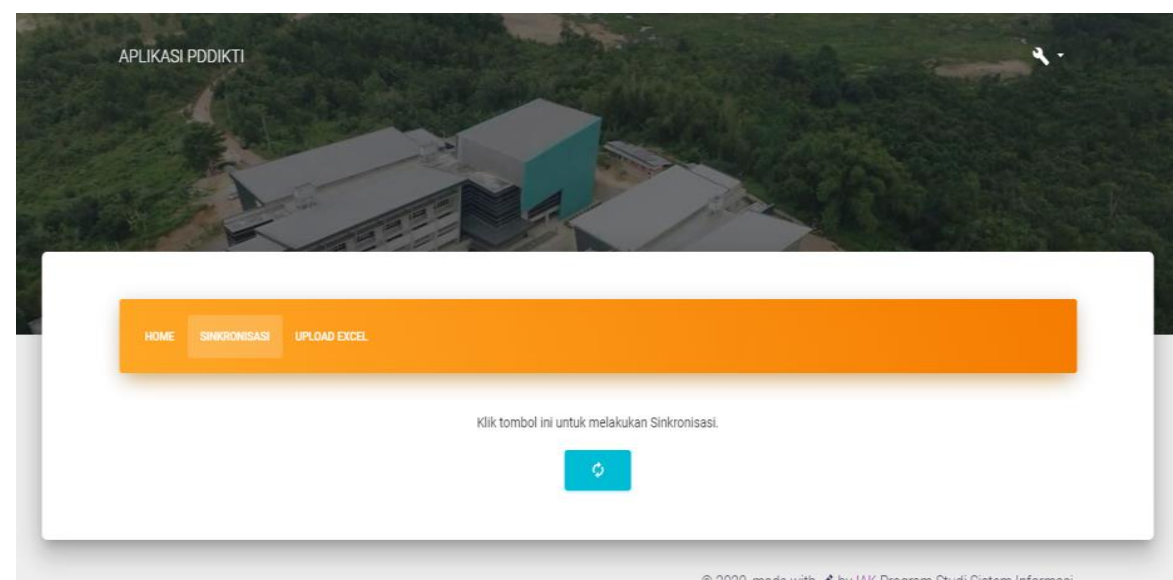

Gambar 7: Halaman Sinkronisasi

Gambar 7 merupakan tampilan aplikasi untuk sinkronisasi didalamnya hanya ada satu tombol yang digunakan untuk mensinkronisasi data dari basis data dengan Feeder PDDIKTI.

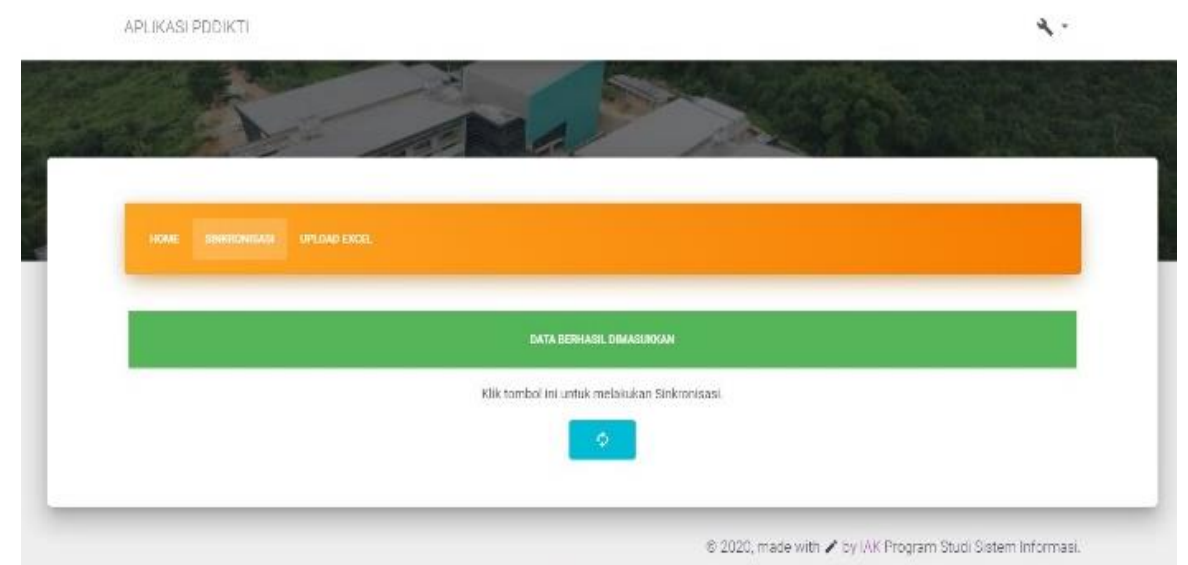

Gambar 8: Halaman Berhasil Sinkronisasi

Gambar 8 merupakan tampilan aplikasi jika pengguna telah menekan tombol sinkronisasi dan sistem telah berhasil untuk memigrasikan data ke Feeder PDDIKTI. 


\subsection{Pengujian Program}

Setelah dilakukan pengkodean pada program, dilakukan pengujian tingkat pengguna terhadap program yang dibuat. Berikut merupakan hasil dari pengujian program yang menggunakan metode black box.

Tabel 4: Pengujian program

\begin{tabular}{|c|c|c|c|c|}
\hline No & Fitur & Skenario & Hasil yang Diharapkan & Kesimpulan \\
\hline 1 & $\begin{array}{l}\text { Integrasi data dari } \\
\text { SIKANTAN ke } \\
\text { Feeder PDDIKTI }\end{array}$ & $\begin{array}{l}\text { Admin melakukan } \\
\text { login ke sistem. } \\
\text { Setelah itu, membuka } \\
\text { halaman sinkronisasi } \\
\text { dan menekan tombol } \\
\text { sinkron. }\end{array}$ & $\begin{array}{l}\text { Terdapat tampilan yang } \\
\text { menyatakan bahwa data } \\
\text { berhasil disinkronisasi }\end{array}$ & Berhasil \\
\hline 2 & Login & $\begin{array}{l}\text { Admin membuka } \\
\text { aplikasi, lalu } \\
\text { memasukkan nama } \\
\text { pengguna dan kata } \\
\text { sandi pada halaman } \\
\text { login. }\end{array}$ & $\begin{array}{l}\text { Admin berhasil masuk ke } \\
\text { halaman sinkronisasi data }\end{array}$ & Berhasil \\
\hline
\end{tabular}

\section{Kesimpulan}

Aplikasi untuk menyinkronkan data dari SIKANTAN ITK, yaitu SIAKAD ke dalam aplikasi Feeder PDDIKTI dapat menjadi solusi dari permasalahan yang dihadapi. Dalam pengembangannya dilakukan dengan indentifikasi masalah, studi literatur, analisis kebutuhan yang terdiri dari pembuatan use case diagram, deskripsi use case, kebutuhan perangkat lunak, kebutuhan perangkat keras, kemudian tahapan desain dan arsitektur terdiri dari pemetaan data, proses data, struktur navigasi dan method web service. Selanjutnya dilakukan coding dan pengujian dengan blackbox, menghasilkan 2 fitur diujikan sukses. Dengan adanya aplikasi ini, perguruan tinggi dapat dengan mudah melakukan migrasi data. Hal ini juga untuk menunjang pembaruan data agar tidak dilakukan penginputan data secara tidak efektif dan efisien. Namun, dalam penelitian kali ini hanya dilakukan proses migrasi data mahasiswa. Penerapan web service dalam integrasi data akademik sangat membantu dalam pertukaran data secara otomatis dengan kode token yang sudah disediakan, sehingga web service sebagai protokol pertukaran data mendapatkan informasi yang lengkap sesuai dengan integrasi data yang sesuai dengan arsitektur yang dibangun.

\section{Daftar Pustaka}

Abbas, W. (2013) 'Analisa kepuasan mahasiswa terhadap website Universitas Negeri Yogyakarta (UNY)' dalam Prosiding Seminar Nasional Sains dan Teknologi, Semarang, Indonesia: SNST.

Hendrianto, D. E. (2013) 'Pembuatan sistem informasi perpustakaan berbasis website pada sekolah menengah pertama negeri 1 Donorojo kabupaten Pacitan', Indonesian Journal on Networking and Security, Vol. 4, No. 3: 57-64.

Kenali, E. dan Fatoni, H. (2014) 'Desain dan implementasi service provider berbasis web services push pangkalan data perguruan tinggi pada sistem informasi Akademik Politeknik Negeri Lampung' dalam Prosiding Seminar Bisnis \& Teknologi 2014 IBI Darmajaya, Bandar Lampung, Indonesia: SEMBISTEK.

Lestanti, S. dan Susana, A. D. (2016) 'Sistem pengarsipan dokumen guru dan pegawai menggunakan metode Mixture Modelling berbasis web', Jurnal Antivirus, Vol. 10, No. 2: 69-77.

Nurajizah, S. (2016) 'Implementasi multimedia development life cycle pada aplikasi pengenalan lagu anak-anak berbasis multimedia', Jurnal PROSISKO, Vol. 3, No. 2: 14-19. 
Pemerintah Indonesia. (2012) Undang-Undang Nomor 12 Tahun 2012 tentang Pendidikan Tinggi Pasal 56, Jakarta: Sekretariat Negara.

Perwira, R. I. dan Santosa, B. (2017) 'Implementasi web service pada integrasi data akademik dengan replika pangkalan data dikti', TELEMATIKA, Vol. 14, No. 1: 1-11.

Priyambodo, T. K. (2005) 'Implementasi web-service untuk pengembangan sistem layanan pariwisata terpadu' dalam Prosiding Seminar Nasional Aplikasi Teknologi Informasi, Yogyakarta, Indonesia: SNATI.

Sasongko, A. (2017) 'Integrasi data website STUDENTS.BSI.AC.ID untuk mobile info kampus berbasis android menggunakan ekstraksi HTML', Jurnal Ilmu Pengetahuan Dan Teknologi Komputer, Vol. 2, No. 2: 146-155.

Sutrisno, M. A. dan Muhsi, M. (2016) 'Pengembangan sinkronisasi sistem informasi akademik dengan feeder PDDIKTI menggunakan Framework Laravel' dalam Prosiding Seminar Nasional Humaniora \& Aplikasi Teknologi Informasi 2016, Pamekasan, Indonesia: SEHATI.

Usman, S. (2020) 'Implementasi sistem informasi akademik dengan feeder PDDIKTI berbasis android', Journal of System and Computer Engineering (JSCE), Vol. 1, No. 1: 28-37.

Widarti, E., Bahri, S. dan Widyanto, A. (2018) 'Integrasi Sistem Informasi Akademik Terpadu (SIAKAT) dengan feeder PDDIKTI', Journal Informatic Technology And Communication, Vol. 2, No. 3: 10-18.

Widodo, S., Brawijaya, H., Samudi, S., dan Retnoningsih, E. (2018) 'Integrasi data akademik dengan aplikasi feeder PDDIKTI berbasis web service’, BINA INSANI ICT, Vol. 5, No. 2: 153-162. 